\title{
THE SHRINKING PROFESSORIATE: ACADEMIC PROMOTION AND UNIVERSITY TEACHING
}

\author{
R. Subbaye \\ University Teaching and Learning Office \\ University of KwaZulu-Natal \\ Durban, South Africa \\ e-mail: subbaye@ukzn.a.cza
}

\section{ABSTRACT}

The rank progression intentions of South African associate professors is important given the declining numbers of full professors in the country. By focusing on a large South African research university where both research and teaching criteria are recognised for promotion to full professor, this article explores associate professors' perspectives on academic promotion and the role of teaching as a criterion. Key findings from an on-line survey and interviews are that; age and the number of years spent in the rank play a significant role in influencing intentions to become a full professor (or not), there is dissatisfaction with the level of support for promotion applications and, more women than men expressed positive perspectives about teaching as a criterion in promotion. The study points to how academic promotion processes, criteria and support could be enhanced to increase the number of full professors in South Africa.

Keywords: academic promotion; higher education; professoriate; university teaching; academic rank progression; South Africa

\section{INTRODUCTION}

The transition to full professor is often considered as a rite of passage in an academic career and signifies the recognition of professional accomplishment (Bitzer 2008, 265; Gardner and Blackstone 2013, 411). Full professors are knowledge-producers and decision-makers in the academy. In many cases they constitute senior university leadership. They are accorded: status, prestige, relative autonomy, independence to pursue their scholarship and, a higher pay grade (Enders 2001, 5; Pedro 2009, 418; Sanfey 2010, 557).

South African universities in particular, face difficult and unprecedented challenges with a shrinking professoriate which is not being replenished at the rates required to sustain the growth of the higher education sector. However, offset against public-demands for racial and gender diversity to redress historic apartheid inequities (Sehoole and Ojo 2015, 266); simply filling professorial positions by turning a blind eye to the requirements for academic excellence is not an option because universities could risk damaging their institutional reputation and 
international recognition (Bitzer 2008, 278). Associate professors are therefore important as the potential pool of future full professors in the country. One way to become a full professor is through academic promotion but attaining the rank of full professor is a long and difficult journey. Academics who achieve this rank need to demonstrate evidence of a national and international reputation which, derived from peer-credibility, marks their standing in the academic community (Bitzer 2008, 278).

Studies on rank progression have focussed on understanding the trajectories of early career academics from doctoral studies into junior ranks in the academy and supporting their subsequent transition over time (see Reybold 2003, 235; Lindholm 2004, 603; Young 2006, 191; Toews and Yazedjian 2007, 119; Green 2008, 117; Finnegan and Hyle 2009, 443; McAlpine 2014, 835; Sehoole and Ojo 2015, 253; Waaijer 2015, 43). The few studies that explicitly examine promotion from associate professor to full professor show that institutions, academic departments and individual associate professors have differing expectations of promotion processes and criteria (Buch, Huet, Rorrer and Roberson 2011, 44; Crawford, Burns and MacNamara 2012, 43; Wilson 2012, 1; Gardner and Blackstone 2013, 418; Matthews 2014, 4). These studies show that research productivity is often the main determinant of promotion to full professor, with teaching playing a minor role in the promotion decision at this rank (if at all).

Typically, professors within any discipline are expected to; show sustained excellence in their scholarly endeavours (Sanfey 2010, 554), be better qualified, have published more research than non-professors, undertake leadership responsibilities and, carry out academic management roles (Rayner, Fuller, McEwen and Roberts 2010, 621). Given the knowledge generation demands of a developing society which are exacerbated by declining numbers of full professors in the country, the rank progression intentions of South African associate professors become important. This raises questions about associate professors' expectations regarding academic promotion to full professor and how they feel about teaching being used in the promotion decision, taking into account the obligations for research productivity at this rank.

\section{PROFILE OF THE SOUTH AFRICAN PROFESSORIATE}

Since the associate professor rank acts as a pipeline to full professor. It is important to understand the composition of these ranks especially in South Africa, where the higher education sector is expanding - much like the rest of the continent, and the demands for knowledge production in this developing context are increasing (Teferra 2014, 9). South 
African academic staffing by rank spanning two decades shows that full professors as a proportion of staff is decreasing over time (Figure 1). While it was expected that full professors would represent the smallest proportion of academics, the proportion of associate professors, the smallest category of academic staff in South Africa, decreased from 10 per cent in 1992 to 7 per cent in 2014. Of concern is the overall shrinking numbers in the professoriate (in the ranks of both full professor and associate professor). This could have negative implications for knowledge production and academic leadership over time.

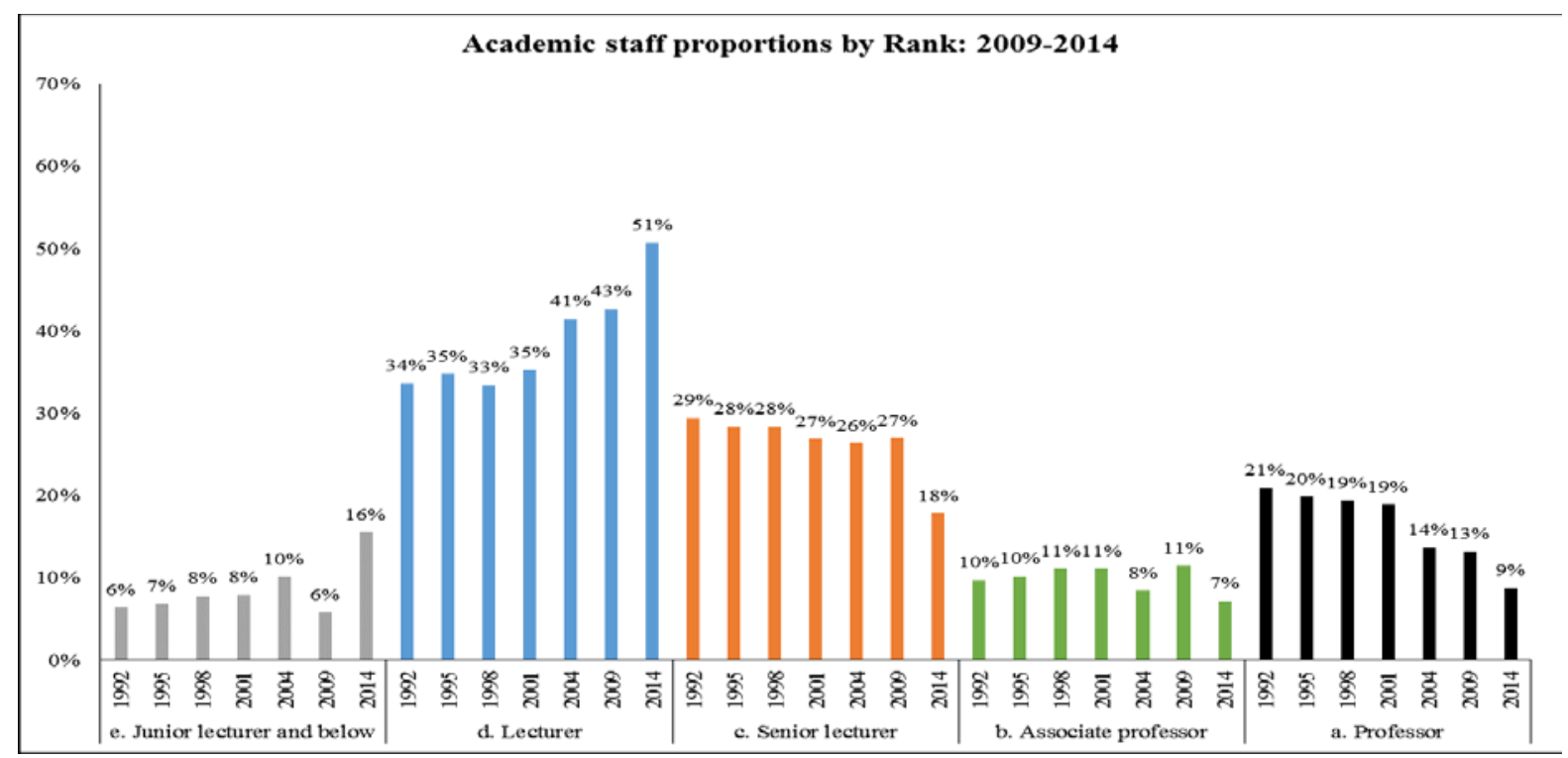

Data sources: 1992, 1995, 1998 and 2001 (Boshoff 2005); 2004 (CHE 2016); 2009 (HESA 2011); 2014 (DHET 2016a)

Figure 1: Proportions of academic staff by rank in South African universities (1992-2014)

In South Africa considerable attention is being paid to the composition of the professoriate specifically with regard to who are they and how many there are. In order to redress the historical disadvantages inherited from apartheid and to achieve equity in the workplace; universities are required by law to take reasonable measures to ensure compliance with the Employment Equity Act $^{1}$ (South African Government 1998) in line with the country's Constitution. They have to account for gender and racial representation in the academy.

Recent media reports show that universities are under pressure to explain why there are so few Blacks ${ }^{2}$ in the professoriate in post-apartheid South Africa. Although the number of Black academic staff at each rank level has increased, the professoriate has remained largely White (Figure 2). For the period 2009-2014 the proportional representation of Blacks has averaged 32 per cent at the rank of full professor and was even smaller at 22 per cent at the rank of associate professor. From the viewpoint of Black academics, the shortage in the professoriate 
is due to the lack of supportive networks, and hostile institutional cultures (grounded in White norms) which create a 'chilly climate' in the academy and act as barriers to rank progression (Potgieter 2002, 26-27; Mkhwanzi and Baijnath 2003, 109). From university leadership perspectives, the dearth of Black professors is largely due to the unattractiveness of academia as a profession for first-generation university students who, in their drive to support their families, take jobs which offer better pay than the academy resulting in the high turnover of Black staff (Jansen 2015, 1); the small pool from which to draw future Black professors since a long period of time elapses between getting a $\mathrm{PhD}$ and becoming a professor (Price 2014, 1) and under-funding from government for postgraduate studies, resulting in the production of too few doctoral graduates (Habib 2014, 1).

Although few would disagree that there is a problem, there is less consensus on how existing rank progression models might be serving as gatekeepers into the professoriate and more importantly, what could be done institutionally to ameliorate the situation. Black associate professors represented the smallest proportion of academic staff by rank in South African higher education between 2009 and 2014 (Figure 2).

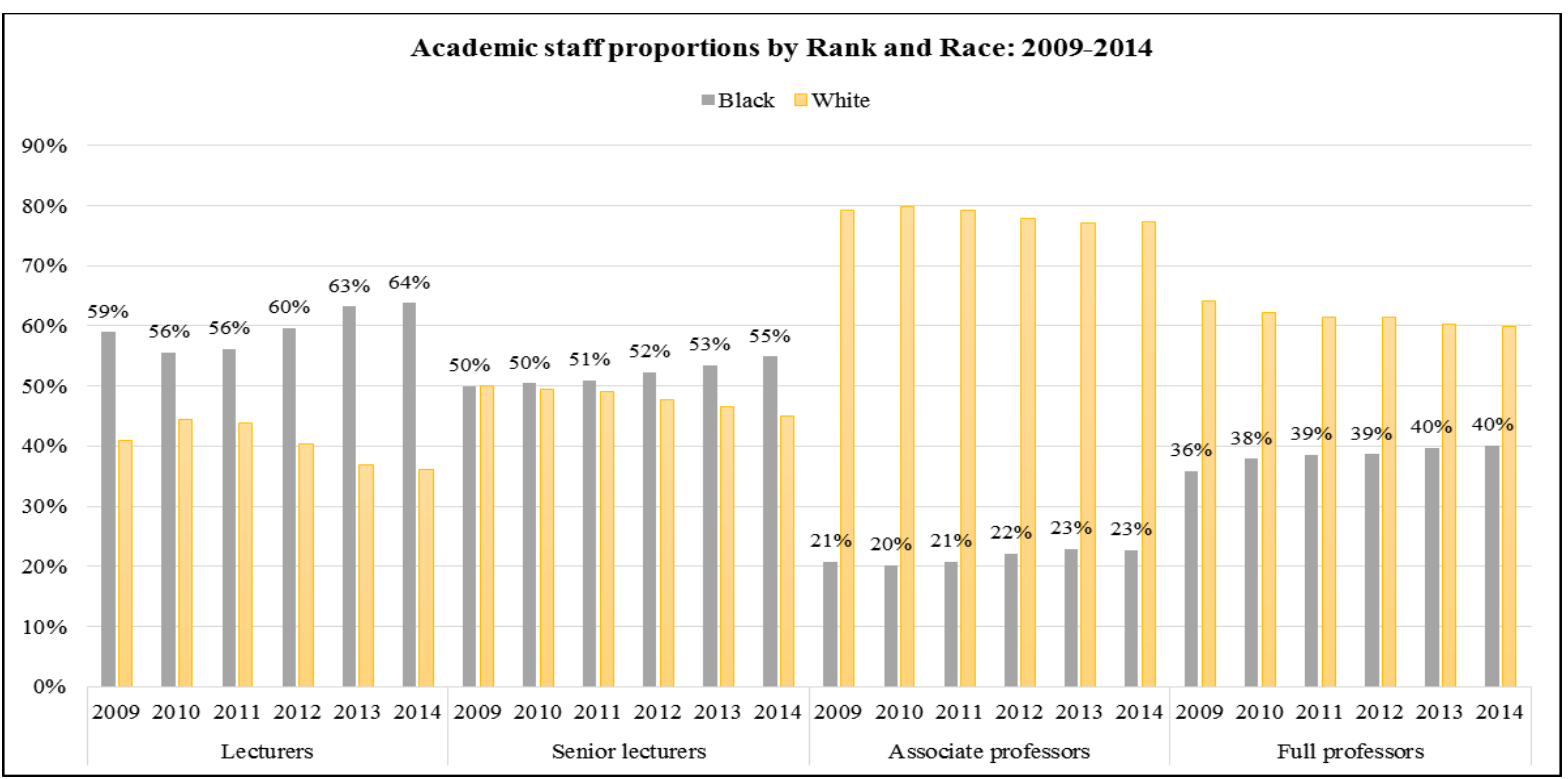

Data source: 2009-2014 (DHET 2016a). Dataset includes all temporary and permanent staff coded as instructional research professionals

Figure 2: South African academic staff by rank and race: 2009-2014

While Figure 3 indicates that women are over-represented in the ranks of lecturer and underrepresented in all other ranks, Subbaye and Vithal $(2016,2)$ demonstrated that the gender-gap in the higher ranks was diminishing. However, studies have shown that the trend toward gender parity is progressing at a slow rate given the country's constitutional commitment to gender 
equity (Boshoff 2005, 360; Subbaye and Vithal 2016, 3). Buch et al. (2011, 41) reported that in the US, more women than men tended to 'stand still' at the rank of associate professor. This is reflective of what seems to be happening in South Africa, with more women represented in the rank of associate professor than in that of full professor, suggesting that this transition might be particularly challenging for women academics.

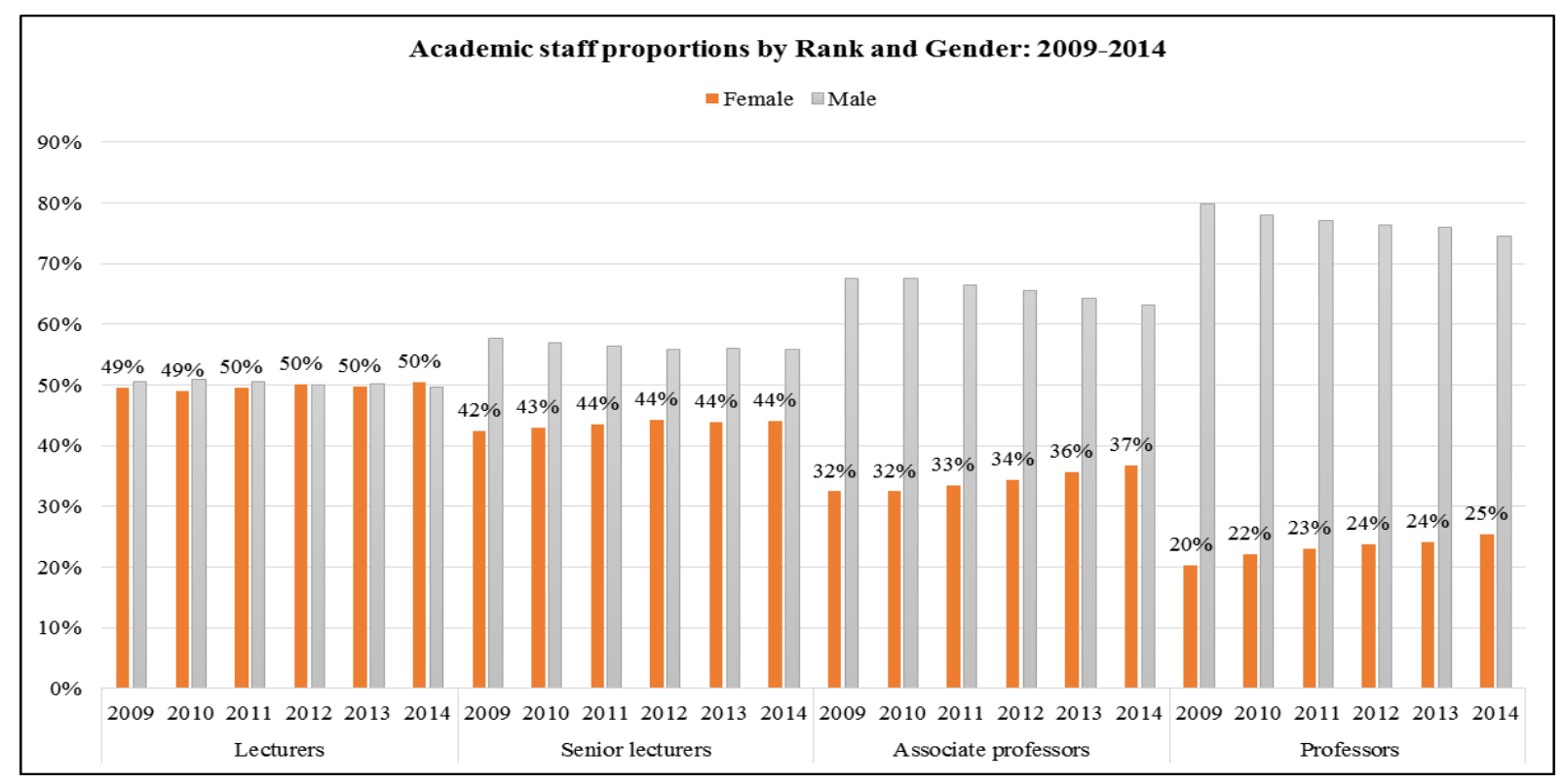

Data source: 2009-2014 (DHET 2016a). Dataset includes all temporary and permanent staff coded as instructional research professionals

Figure 3: South African academic staff by rank and gender: 2009-2014

\section{PROMOTION PROCESSES AND CRITERIA}

Promotion processes are typically based on the collective judgments of various committees comprising peers, senior academics and university officials. Differences among universities may include the number of levels of adjudication and moderation as well as differences in the criteria used for appraisal (Ornstein, Stewart and Drakich 2007, 5). What is common is that promotion to full professor is still largely dependent on research productivity (Macfarlane 2011, 59; Crawford et al. 2012, 51; Cretchley, Edwards, O’Shea, Sheard et al. 2014, 2; Altbach 2015, $6)$.

Altbach $(2015,6)$ and Probert $(2013,2)$ explain that reliance on research is related to the growing importance of university rankings, where indicators of university performance are skewed toward research rather than measures such as teaching and learning. This imbalance in the criteria considered for promotion has led to discontent among academics. Wilson $(2012,1)$ found that associate professors were the unhappiest people in the US academy largely because they spent too much time doing service work and not enough research which diminished their 
competitiveness and limited their career options. Hence the dependence on research criteria to assess associate professors for promotion to full professor is being challenged.

More universities around the world are starting to create alternative pathways and recognising more than just research productivity such that associate professors can be promoted to full professor (Probert 2013, 17). In South Africa nine universities consider teaching in their academic promotions but its application is limited to junior ranks and the 'minimum requirements for promotion to the higher levels are biased towards research at the expense of teaching ...' (CHE 2015, 102).

Therefore, by using the case of one South African university where research and teaching are evaluated for promotion to full professor (Vithal, Subbaye and North 2013, 323), this article explores the intentions of associate professors in becoming full-professors. The specific research questions were: what are associate professors' perspectives on becoming fullprofessors in future; what are their perspectives on academic promotions and what do they think about teaching as a criterion for promotion to full professor?

\section{CONTEXT AND METHODOLOGY}

In 2014 five of the 25 universities in South Africa produced more than half (52.6\%) of all the publication-outputs in the country. These universities were the: University of KwaZulu-Natal (UKZN), University of Pretoria (UP), University of Cape Town (UCT), Stellenbosch University (SU) and the University of the Witwatersrand (Wits). Together these universities compromised the top five research-productive universities in the country (DHET 2016b, 2829). Figure 4 demonstrates that even at these research universities the proportion of staff in the rank of associate professor has decreased from 2009 to 2014. Furthermore, when examining the staff headcounts in the ranks of associate professor and full professor by race and gender in 2014, Figure 5 shows that White males dominate the professoriate (at both associate- and fullprofessor ranks) and that, Blacks and females are under-represented in varying proportions across all five research universities.

The University of KwaZulu-Natal (UKZN), which is a large contact university (Bunting and Cloete 2010, 3), is ranked as the top research-productive university in South Africa (DHET 2016b, 28). UKZN recognizes teaching in academic promotions to full professor (Subbaye and Vithal 2015, 5). Hence insights from UKZN's associate professors' perspectives on promotion could have implications for growing the professoriate via academic promotion nationally and in research universities in particular. 


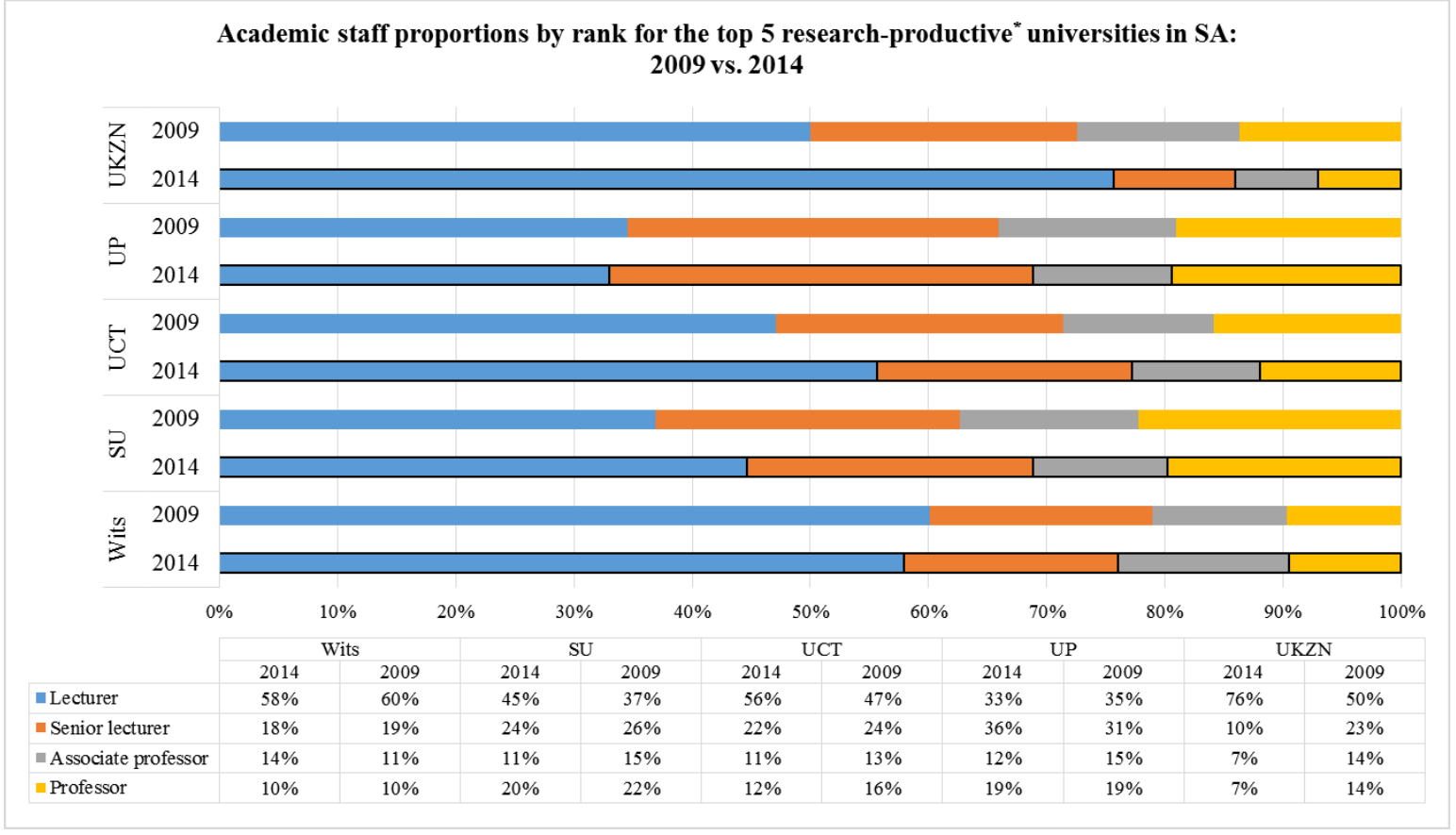

Data source: 2009 and 2014 (DHET 2016a). Dataset includes all temporary and permanent staff coded as instructional research professionals in 2009 and 2014.

*DHET $(2016 b, 29)$

Figure 4: Proportions of academic staff by rank at UKZN (2009-2014)

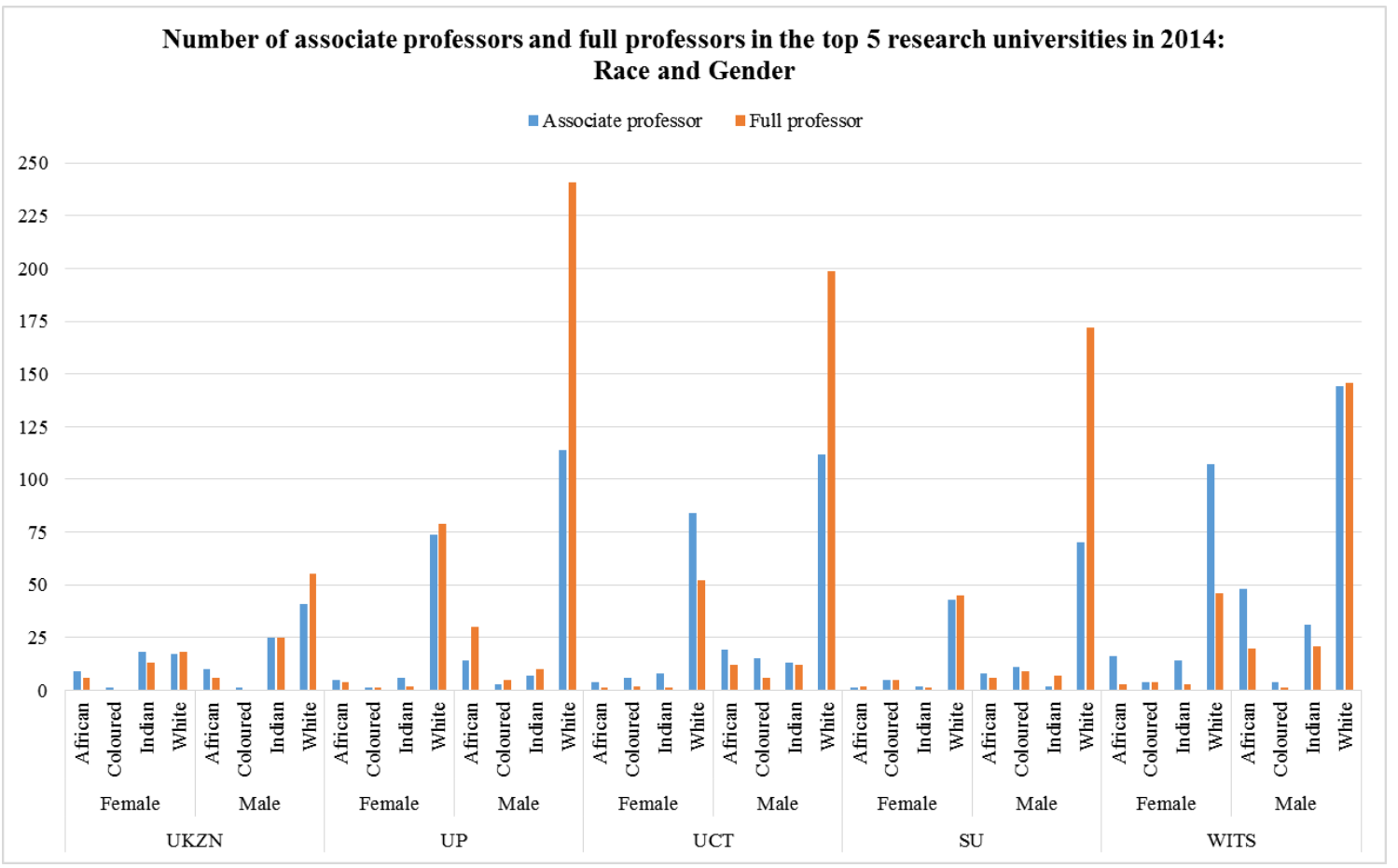

Data source: 2014 headcounts (DHET 2016a). Dataset includes all temporary and permanent staff coded as instructional research professionals in the ranks of associate and full professor.

Figure 5: Number of staff in the professoriate in 2014 by Race and Gender 
Promotion to full professor at UKZN is merit-based (UKZN 2011, 4) and has the mandatory requirement that applicants demonstrate strength in both research and teaching and excellence in two of the four main areas in the promotions policy (teaching, research, university service and community engagement) (Subbaye and Vithal 2015, 5). Applications for all rank levels require the submission of teaching portfolios. Details on the academic promotion process and associated appraisal criteria are reported elsewhere (also see Vithal et al. 2013, 322; Subbaye and Vithal 2015, 5). Despite the equal valuing of teaching and research in promotions policies and processes for over a decade, perceptions among academic staff at the university are that research matters more for promotion and that teaching is not valued. Therefore, examining UKZN's associate professors' perspectives on teaching as a criterion for promotion to full professor could contribute to a broader understanding of the perceived under-valuing of teaching at UKZN.

An on-line survey provided a profile and snapshot of associate professors' perspectives on academic promotions and the use of the teaching criterion at the university; and produced data that enabled a group analysis of these perspectives. Interviews with 5 associate professors provided explanations for the quantitative results generated from the survey. Ethical clearance to conduct this study was obtained as part of a larger doctoral project (Subbaye 2014). The survey was developed using LimeSurvey (2015) and hosted on a secure server (no public access) to ensure confidentiality of the respondents. A pilot study was conducted to assess the feasibility, ease of use and time to complete the online survey and to reduce potential ambiguities in the survey statements and categorical response variables $(n=8)$.

A list of the email addresses of all associate professors $(n=126)$ at UKZN was obtained from the University's Human Resources division. In July 2015, an email invitation containing an explanatory brief (informed consent), copies of the ethical clearance document and the gatekeeper's permission letter, and the link to an online survey was sent to these associate professors. The survey was available in English and open for participation for a total of six weeks. Three follow-up requests for participation were sent each fortnight. Responses to the on-line survey were exported to IBM SPSS Statistics 23 (SPSS 2015) and all metadata on participants were scrubbed from the exported file to safeguard the anonymity of the respondents.

A total of 39 associate professors (AssocProfs) responded, resulting in a 31 per cent response rate. Eight individuals who did not classify their gender and/or did not respond to more than half the survey questions were excluded from the analysis. Another eight elected not to participate in the survey, citing busy work schedules $(n=3)$, leave $(n=2)$, fear of reprisal $(n=2)$ 
and inability to access the survey on-line $(n=1)$.

Measures in the analysis included two outcome variables (OV), namely 'OV1: intention to become a full professor in future' and 'OV2: intention to apply for promotion at UKZN to become a full professor in future'. The outcome variables were coded with dichotomous responses where ( $1=$ No, $2=$ Yes). These variables were measured by the survey statement ' $\mathrm{I}$ would like to become a full professor by:' Possible responses to this statement were: 1=Applying for promotion at UKZN; 2=Applying for a vacancy at UKZN, 3=Applying for a vacancy at another university, and 4= I have no intention of become a full professor in future. Survey statements were measured using Likert scales ranging from strongly disagree to strongly agree (where 1 =strongly disagree, 2=disagree, $3=$ =uncertain, $4=$ =agree, $5=$ =strongly agree).

Descriptive analyses included frequencies, cross-tabulation, and measures of central tendency. Thereafter Cronbach's Alpha $(\alpha)$ co-efficient was used to determine the internal reliability and consistency of the constructs on perspectives on promotion. A value greater than 0.7 was considered reliable (Field 2009, 675). Seventeen items in the analysis appeared to be worthy of retention (Cronbach's Alpha=0.767). Missing data was excluded from the analysis which accounts for the varying denominators throughout the analysis.

Binomial tests were conducted to determine whether there were any statistically significant differences in the proportions of responses $p\left(\mathrm{H}_{1}\right)$ compared to the presumed test proportions of $p\left(\mathrm{H}_{0}\right)=0.50$ for each survey statement (Likert scales were recoded to $0=$ Disagree and 1=Agree for this test). Notwithstanding the small sample size, t-tests were then used to compare the means of two independent groups in order to determine if there were any statistically significant differences between the groups (where $p<0.05$ and effect size $d>0.7$ ). De Winter $(2013,6)$ showed that applications of the t-test to small samples provided Type I error rates close to the 5 per cent nominal value in most cases, provided that the effect sizes were large ( $d>.7)$, and resulted in acceptable statistical power (i.e., 80\%). Where relevant the median was used to split the groups (i.e., age and number of years in rank). The analysis aimed to determine if there were any statistically significant differences (with large effect sizes) in perspectives on academic promotions among associate professors for seven different groupings:

i) Gender (1=female; $2=$ male),

ii) Race (1=black, $2=$ white),

iii) Age (1= Less or equal to 50 years, 2=Greater than 50 years),

iv) Discipline ( $1=$ Sciences and $2=$ Social Sciences)

v) Years in the rank (1=less than 5 years; $2=$ greater than 5 years),

vi) Intention to become a full professor in future (1=no; 2=yes), and 
vii) Intention to apply for promotion to full professor at UKZN in future (1=no, 2=yes).

Pursuant to the on-line survey five associate professors from the 4 Colleges were interviewed to get a deeper understanding of their perspectives about academic promotion and the role of teaching. Quotes from these interviews and comments from the on-line survey are used to substantiate results with significant differences. Finally, the results reported from the survey do not represent any group apart from itself. Therefore, the parameters for generalizability from this sample to the larger population of associate professors is limited.

\section{MAIN FINDINGS}

A descriptive profile of the survey respondents (Tables 1 and 2) and interview participants (Table 3) is provided and mainly results that demonstrate statistically significant differences (Tables 4 and 5) are subsequently reported. The quantitative results are substantiated by comments from the on-line survey and quotes from the interviews. The findings are broadly categorized by perspectives on: becoming full-professors, applying for promotion, the promotion processes and the promotion criteria.

\section{Descriptive profile of the respondents}

Of the 31 associate professors there were more male $(n=19)$ than female $(n=12)$ respondents. Twelve South African Blacks, 11 Whites and 8 foreign nationals participated in the study. There was an almost even distribution of AssocProfs by age ( $n=16 \leq 50$ years and $n=15>50$ years), and number of years in the rank ( $n=16 \geq 5$ years and $n=15<5$ years). The majority of the respondents were from the Sciences $(n=20)$ with $n=11$ from the Social sciences. More respondents became associate professors by applying for promotion from senior lecturer at the university ( $n=19)$ than those who applied for a vacancy at the rank of associate professor $(n=12)$ (Tables 1 and 2). The next section provides a description of the respondents' intentions of becoming (or not) full professors in the future and their perspectives on academic promotions processes and criteria at the university.

\section{On becoming a full professor and applying for promotion (or not)}

The results showed that the majority of the associate professors wanted to become full professors in future $(n=20)$. Their main motivations were to be a leading scholar in their disciplinary field $(n=10)$, to achieve a sense of accomplishment $(n=4)$, international recognition for their work $(n=4)$; financial security $(n=1)$ and to become a deputy vice-chancellor $(n=1)$. Most associate professors intended to apply for promotion at UKZN ( $n=17)$ with $n=3$ opting to 
apply for a vacancy at another university.

Younger associate professors wanted to become full professors $(\mathrm{t}(31)=2.086, p=0.046$, $d=1.200)$ and intended to apply for promotion ( $\mathrm{t}(31)=2.481, p=0.019, d=1.272)$ compared to older associate professors. Similarly academics in the rank for less than five years wanted to become full professors $(\mathrm{t}(31)=2.700, p=0.011, d=1.290)$ and intended to apply for promotion $(\mathrm{t}(31)=2.077, \mathrm{p}=0.047, d=1.196)$ compared to those who were older and those who remained in the rank for longer than 5 years. As explained by an interview participant who did not want to apply for promotion.

If I work really hard at the [promotion] application and so on. I'm going to have the full professorship for a year. Is it really worth it? I don’t know. I don’t think so. (Interview \#3)

In particular Black academics agreed that once one became an associate professor there was an expectation from one's peers that one would eventually become a full professor compared to White professors $(\mathrm{t}(31)=2.086, p=0.050, d=.890)$ (Table 5). Pressure to meet these expectations may be compounded by an intrinsic motivation to grow the small number of full professors who are Black as mentioned by an African female associate professor who aspires to become a full professor:

We still dealing with the impact of the apartheid. Why? Can you believe I am the only black South African woman here? Black African, not Coloured or Indian. I am the only one. At UNISA I think there are 5 now. AT Wits there's one. At UP and UJ, none. UCT and Stellenbosch, none. All the universities in the Eastern Cape, none. No women in [discipline removed to preserve anonymity]. We [black African females] are less than 10 in the country. (Interview\#2)

Those respondents who did not want to become a full professor in future $(n=11)$ cited the following reasons: the promotion criteria and processes at UKZN were challenging $(n=5)$; upcoming retirement from the academy $(n=3)$; there is no distinction between associate and full professors $(n=2)$; and that the UKZN culture was hostile $(n=1)$.

Two of the associate professors (one White female and one Black male) both of whom were from the Social Sciences, aged $\geq 50$ years and in the rank for more than five years, indicated that they had made prior applications for promotion to full professor. The male reported making two previous attempts and was unsuccessful in both bids because his teaching portfolio was rated at strength. He intended to become a full professor by applying for promotion elsewhere. The female indicated that she had made one attempt and was unsuccessful because she did not meet the research criterion. She did not intend to apply again because she would be retiring shortly. Both these respondents indicated that they did not receive any useful feedback after unsuccessful attempts at promotion to full professor and did not think 
that teaching should be a core criterion in promotions.

\section{On the promotions process}

Associate professors were asked to rate their views on the transparency of the promotion application process and its associated timelines. This study found that those in the rank for less than five years thought that the timelines were appropriate compared to those who were in the rank for longer (Table 5: $\mathrm{t}(31)=2.385, p=0.024, d=.871)$.

With regard to support before and during the promotion process, associate professors who intended to apply for promotion reported that prior support to develop a teaching portfolio was readily available compared to those who had no intention of applying for promotion (Table 5: $\mathrm{t}(31)=-2.4755, p=0.021, d=.902)$. However, one interviewee pointed out that building a portfolio takes time yet the support provided by the Quality Promotions and Assurance division (QPA) at the university is a short-term event.

You need to build a teaching portfolio over years ... that is what makes a very good teaching portfolio. So, the experience of building the portfolio is very critical. Sure, QPA does really try. They will say 'We want to help you all to work on your teaching portfolios one afternoon, or even on one day'. But it’s not a day thing. (Interview \#4)

Older associate professors did not think that there was adequate support from senior staff and younger associate professors were unsure if such support was available to them (Table 5: $\mathrm{t}(31)=2.298, p=0.029, d=.833)$. An interviewee pointed out that in her discipline there were too few senior staff to provide support for promotions:

My boss - he always tells me you are the senior academic here. You should take the initiative. But I don’t have support. I am on my own. (Interview\#2)

Perspectives on the committees that decide on promotion applications showed that younger associate professors seemed satisfied with the overall conduct of the decision-making committees compared to older associates professors, who disputed that the committees made decisions in a fair manner $(\mathrm{t}(31)=2.461, p=0.021, d=.899)$. Furthermore older associate professors were not convinced that these committees communicated in a transparent manner about the outcome $(\mathrm{t}(31)=2.747, p=0.011, d=1.00)$ (Table 5).

\section{On the promotion criteria}

Associate professors who wanted to become full professors in future $(\mathrm{t}(31)=-2.533, p=0.018$, $d=.881)$ and specifically those who intended to apply for promotion $(\mathrm{t}(31)=-2.297, p=0.033$, $d=.935$ ) felt that all the criteria currently used at UKZN were relevant. However, older 
respondents $(\mathrm{t}(31)=2.260, p=0.032, d=.825)$ and those who had been in the rank longer than five years ( $\mathrm{t}=2.924, p=0.007, d=1.072)$ did not think the criteria were relevant (Table 5). One interviewee had this to say about the relevance of the criteria to his work:

I think quite a lot of thought was put into the teaching so that it's not lagging behind research. But ... I'm doing all this wonderful community service and you guys don't have a metric for allowing me to be valued alongside the people who are doing teaching and, the people who are pumping out papers. (Interview\#1)

Most respondents felt that the criteria for promotion (research and teaching) at UKZN were more difficult to meet than at other comparable universities (Table 4: $n=21, p\left(\mathrm{H}_{1}\right)=0.04$ ). One interviewee explained that the teaching criteria specifically have become more onerous over time compared to a pre-merger institution:

That was in 2002 ... I could be mistaken. But at that time ... it was at then-University of Natal. I guess promotion was a little bit more lax. You must have had a teaching portfolio obviously, which I had ... but the criteria and the different aspects were not as onerous as they are presently (Interview\#4)

In addition most respondents did not think that the criteria adequately accommodated disciplinary differences (Table 4: $\mathrm{n}=19, p\left(\mathrm{H}_{1}\right)=0.011$ ).

If you do an analysis of data all over the country and in fact internationally, certainly my [disciplinary] output of research is not same as the output of say, biology or chemistry. Not all disciplines are the same but we all get measured the same. (Interview\#3)

Associate professors who intended to become full professors did not think that teaching should be a core criterion for promotion.

The teaching portfolio should not be a compulsory criteria for promotion for a research-led university like UKZN (online respondent \#36).

By contrast, those who did not intend to become a full professor agreed that teaching should be a criterion for promotion (Table 5: $\mathrm{t}(31)=2.564, p=0.019, d=.981$ ). Despite these divergent views on using teaching in promotions, most respondents felt the criteria currently used to evaluate the teaching portfolio were comprehensive (Table 4: $n=19, p\left(\mathrm{H}_{1}\right)=0.015$ ) with statistically significant differences between those who agreed and those who disagreed with this survey statement.

Women associate professors in particular felt that the criteria used to assess the teaching portfolio for promotion were comprehensive $(\mathrm{t}(31)=2.591, p=0.015, d=.927)$ and that the distinction between the teaching portfolio ratings of strength and excellence were apparent to 
them ( $\mathrm{t}(31)=2.637, p=0.015, d=.996)$ (Table 5), as evidenced in the quotes below:

I enjoy teaching. At the same time, I've always put more effort into teaching than into research. And I've done way more than expected even of excellence (Interview\#3).

I haven't started preparing, but I intend to apply for promotion this year. I have to have a teaching portfolio that is more than strength. And I have shown that I've surpassed my research productivity units for three years (Interview\#5).

Table 1: Race, gender and age of survey respondents

\begin{tabular}{|c|c|c|c|c|c|}
\hline \multirow{2}{*}{\multicolumn{3}{|c|}{ Race }} & \multirow{2}{*}{\multicolumn{2}{|c|}{ AGE RANGE }} & \multirow[t]{2}{*}{ Total } \\
\hline & & & & & \\
\hline \multirow[t]{3}{*}{ African } & \multirow{2}{*}{ Gender } & Female & 1 & 2 & 3 \\
\hline & & Male & 1 & 1 & 2 \\
\hline & \multicolumn{2}{|l|}{ Total } & 2 & 3 & 5 \\
\hline \multirow[t]{2}{*}{ Coloured } & Gender & Female & 1 & 0 & 1 \\
\hline & \multicolumn{2}{|l|}{ Total } & 1 & 0 & 1 \\
\hline \multirow[t]{3}{*}{ Indian } & \multirow[t]{2}{*}{ Gender } & Female & 3 & 0 & 3 \\
\hline & & Male & 1 & 2 & 3 \\
\hline & \multicolumn{2}{|l|}{ Total } & 4 & 2 & 6 \\
\hline \multirow[t]{3}{*}{ White } & \multirow[t]{2}{*}{ Gender } & Female & 0 & 3 & 3 \\
\hline & & Male & 3 & 5 & 8 \\
\hline & \multicolumn{2}{|l|}{ Total } & 3 & 8 & 11 \\
\hline \multirow{3}{*}{$\begin{array}{l}\text { Foreign } \\
\text { national }\end{array}$} & \multirow[t]{2}{*}{ Gender } & Female & 1 & 1 & 2 \\
\hline & & Male & 5 & 1 & 6 \\
\hline & \multicolumn{2}{|l|}{ Total } & 6 & 2 & 8 \\
\hline \multirow[t]{3}{*}{ Total } & \multirow[t]{2}{*}{ Gender } & Female & 6 & 6 & 12 \\
\hline & & Male & 10 & 9 & 19 \\
\hline & \multicolumn{2}{|l|}{ Total } & 16 & 15 & 31 \\
\hline
\end{tabular}

Table 2: Becoming an associate professor by College and number of years in rank

\begin{tabular}{|c|c|c|c|c|c|}
\hline \multirow{2}{*}{\multicolumn{3}{|c|}{ I became an associate professor at UKZN by: }} & \multicolumn{2}{|c|}{ Disciplines } & \multirow{3}{*}{$\begin{array}{l}\text { Total } \\
\\
5\end{array}$} \\
\hline & & & \multirow{2}{*}{$\begin{array}{c}\text { Sciences } \\
\text { (includes: } \\
\text { Colleges of } \\
\text { Agriculture, } \\
\text { engineering and } \\
\text { science and } \\
\text { Health sciences) } \\
4\end{array}$} & \multirow{2}{*}{$\begin{array}{l}\text { Social } \\
\text { Sciences } \\
\text { (includes: } \\
\text { Colleges of } \\
\text { Law and } \\
\text { management } \\
\text { studies and } \\
\text { Humanities) } \\
1\end{array}$} & \\
\hline \multirow{3}{*}{$\begin{array}{l}\text { Applying for a } \\
\text { vacancy at } \\
\text { UKZN }\end{array}$} & \multirow{2}{*}{$\begin{array}{l}\text { Number of } \\
\text { years in the } \\
\text { rank }\end{array}$} & Less than 5 years & & & \\
\hline & & $\begin{array}{l}\text { Greater than equal } \\
\text { to } 5 \text { years }\end{array}$ & 6 & 1 & 7 \\
\hline & \multicolumn{2}{|l|}{ Total } & 10 & 2 & 12 \\
\hline \multirow{3}{*}{$\begin{array}{l}\text { Applying for } \\
\text { promotion from } \\
\text { senior lecturer } \\
\text { to associate } \\
\text { professor at } \\
\text { UKZN }\end{array}$} & \multirow{2}{*}{$\begin{array}{l}\text { Number of } \\
\text { years in the } \\
\text { rank }\end{array}$} & Less than 5 years & 8 & 2 & 10 \\
\hline & & $\begin{array}{l}\text { Greater than equal } \\
\text { to } 5 \text { years }\end{array}$ & 2 & 7 & 9 \\
\hline & \multicolumn{2}{|l|}{ Total } & 10 & 9 & 19 \\
\hline \multirow[t]{3}{*}{ Total } & \multirow{2}{*}{$\begin{array}{l}\text { Number of } \\
\text { years in the } \\
\text { rank }\end{array}$} & Less than 5 years & 12 & 3 & 15 \\
\hline & & $\begin{array}{l}\text { Greater than equal } \\
\text { to } 5 \text { years }\end{array}$ & 8 & 8 & 16 \\
\hline & \multicolumn{2}{|l|}{ Total } & 20 & 11 & 31 \\
\hline
\end{tabular}


Table 3: Descriptive profile of interview participants

\begin{tabular}{|c|c|c|c|c|c|c|}
\hline & & $\begin{array}{c}\text { Interviewee } \\
\# 1\end{array}$ & $\begin{array}{c}\text { Interviewee } \\
\# 2\end{array}$ & $\begin{array}{c}\text { Interviewee } \\
\# 3\end{array}$ & $\begin{array}{c}\text { Interviewee } \\
\# 4\end{array}$ & $\begin{array}{c}\text { Interviewee } \\
\# 5\end{array}$ \\
\hline \multirow{2}{*}{ Gender } & Female & & $\square$ & $\square$ & $\square$ & $\square$ \\
\hline & Male & $\square$ & & & & \\
\hline \multirow{2}{*}{ Age } & Less than equal to 50 & & $\square$ & & $\square$ & \\
\hline & Greater than 50 & $\square$ & & $\square$ & & $\square$ \\
\hline \multirow{3}{*}{ Race } & African & & $\square$ & & & \\
\hline & White & $\square$ & & $\square$ & & $\square$ \\
\hline & Foreign national & & & & $\square$ & \\
\hline \multirow{2}{*}{ Time in rank } & Less than equal to 5 years & & $\square$ & & $\square$ & \\
\hline & Greater than five years & $\square$ & & $\square$ & & $\square$ \\
\hline \multirow{2}{*}{$\begin{array}{l}\text { Intends to } \\
\text { become a full } \\
\text { professor }\end{array}$} & Yes & & $\square$ & & $\square$ & $\square$ \\
\hline & No & $\square$ & & $\square$ & & \\
\hline
\end{tabular}

\section{DISCUSSION}

The findings showed that two factors played a significant role in associate professors' perspectives on becoming full professors and academic promotion - age and time in rank. Firstly, younger associate professors intended to become full professors by applying for promotion and had positive perspectives on promotion processes and criteria. One possible reason is that associate professors who are not facing imminent retirement often look for opportunities for demonstrable career progress (Finnegan and Hyle 2009, 444) compared to those who are older and are within five years of retirement, who often seek to extend their careers through consultations and professional organisations (Baldwin and Blackburn 1981, 609) as opposed to pursuing promotion. Putting together an application for promotion takes time and those who are closer to retirement age would rather invest that time preparing for postretirement activities.

Secondly those associate professors who were in the rank for longer than five years did not want to become full professors and had negative views about promotion timelines and criteria. These findings are similar to those of Matthews $(2014,3)$ who found that associate professors who were in the rank for longer than five years, experience a career-slump and as a result were more likely to feel underappreciated by their institutions and dissatisfied with their careers. These associate professors also tended to be more sceptical about promotion outcomes. Therefore, preparation for promotion to full professor should begin soon after promotion to associate professor because this is the best time to reassess opportunities, resources, skills, and career goals (Sanfey 2010, 555). Institutions can support these preparations by designing orientations and providing 'anticipatory guidance’ (Matthews 2014, 5). 
Table 4: Descriptive analysis: Perspectives on promotions (Cronbach's Alpha $=0.767$, number of items $=17$ )

\begin{tabular}{|c|c|c|c|c|c|c|c|c|c|c|c|}
\hline \multirow{2}{*}{$\begin{array}{l}\text { Perspectives } \\
\text { about: }\end{array}$} & \multirow[b]{2}{*}{ Items } & \multirow{2}{*}{$\begin{array}{l}\text { Strongly } \\
\text { Disagree } \\
\text { (1) }\end{array}$} & \multirow{2}{*}{$\begin{array}{l}\text { Disagree } \\
\text { (2) }\end{array}$} & \multirow{2}{*}{$\begin{array}{l}\text { Uncertain } \\
\text { (3) }\end{array}$} & \multirow{2}{*}{$\begin{array}{l}\text { Agree } \\
\text { (4) }\end{array}$} & \multirow{2}{*}{$\begin{array}{l}\text { Strongly } \\
\text { Agree } \\
\text { (5) }\end{array}$} & \multirow[b]{2}{*}{ Mean } & \multirow[b]{2}{*}{ Median } & \multirow[b]{2}{*}{ SD } & \multicolumn{2}{|c|}{ Binomial tests } \\
\hline & & & & & & & & & & $\begin{array}{c}\text { Test } \\
\text { proportion }\end{array}$ & $\begin{array}{l}\text { Exact Sig } \\
\text { (2-tailed) }\end{array}$ \\
\hline \multirow{2}{*}{$\begin{array}{l}\text { Expectations } \\
\text { regarding } \\
\text { promotion to } \\
\text { full professor }\end{array}$} & $\begin{array}{l}\text { At UKZN I think once you become an associate professor, } \\
\text { your peers expect you to become a full-professor }\end{array}$ & 1 & 7 & 4 & 14 & 5 & 3,47 & 4,00 & 1,137 &, 50 & ,076 \\
\hline & $\begin{array}{l}\text { I think there is little difference between the remuneration of } \\
\text { associate professors and full-professors at UKZN }\end{array}$ & 3 & 7 & 14 & 4 & 3 & 2,90 & 3,00 & 1,094 &, 50 &, 585 \\
\hline \multirow{2}{*}{$\begin{array}{l}\text { The } \\
\text { promotions } \\
\text { process at } \\
\text { UKZN } \\
\end{array}$} & I think the promotion procedures are transparent at UKZN & 8 & 4 & 7 & 10 & 2 & 2,80 & 3,00 & 1,349 &, 50 & 1,00 \\
\hline & $\begin{array}{l}\text { I think the time-lines for the promotion-applications } \\
\text { procedure are appropriate at UKZN }\end{array}$ & 3 & 6 & 6 & 13 & 3 & 3,20 & 3,50 & 1,186 &, 50 & ,307 \\
\hline \multirow{2}{*}{$\begin{array}{l}\text { Support for } \\
\text { promotion } \\
\text { applications }\end{array}$} & $\begin{array}{l}\text { At UKZN, I think there is adequate support, from senior staff, } \\
\text { for associate professors who want to apply for promotion }\end{array}$ & 5 & 13 & 8 & 3 & 2 & 2,50 & 2,00 & 1,106 &, 50 & 108 \\
\hline & $\begin{array}{l}\text { I think that support for developing a teaching-portfolio, for } \\
\text { promotion to full-professor is readily available at UKZN }\end{array}$ & 5 & 10 & 4 & 9 & 3 & 2,87 & 3,00 & 1,306 &, 50 & ,845 \\
\hline \multirow{2}{*}{$\begin{array}{l}\text { The } \\
\text { promotions } \\
\text { decision } \\
\text { committees }\end{array}$} & $\begin{array}{l}\text { I am confident the College promotion committees make } \\
\text { decisions about promotion at UKZN in a fair manner }\end{array}$ & 5 & 8 & 8 & 8 & 2 & 2,83 & 3,00 & 1,206 &, 50 & ,832 \\
\hline & $\begin{array}{l}\text { At UKZN I think that the committees which make decisions } \\
\text { about promotion, communicate their decisions in a way that } \\
\text { is transparent about the reasons for the outcome }\end{array}$ & 5 & 10 & 7 & 6 & 3 & 2,77 & 3,00 & 1,251 &, 50 & ,405 \\
\hline \multirow[t]{4}{*}{$\begin{array}{l}\text { The promotion } \\
\text { criteria in } \\
\text { general }\end{array}$} & $\begin{array}{l}\text { I think that there is little difference between the criteria for } \\
\text { applying for a vacancy and the criteria for applying for } \\
\text { promotion, to associate professor at UKZN }\end{array}$ & 7 & 11 & 5 & 6 & 2 & 2,53 & 2,00 & 1,252 &, 50 & 108 \\
\hline & $\begin{array}{l}\text { I think the criteria for promotion to full-professor are more } \\
\text { difficult to meet at UKZN than other comparable universities }\end{array}$ & 3 & 2 & 5 & 4 & 17 & 3,93 & 5,00 & 1,388 &, 50 & $0.004^{*}$ \\
\hline & $\begin{array}{l}\text { I think the promotion criteria adequately accommodate } \\
\text { disciplinary differences }\end{array}$ & 9 & 10 & 7 & 3 & 2 & 2,33 & 2,00 & 1,213 &, 50 & $0.011^{*}$ \\
\hline & $\begin{array}{l}\text { In my view all of the criteria currently used to evaluate } \\
\text { promotions to full professor at UKZN are relevant }\end{array}$ & 8 & 5 & 3 & 9 & 6 & 3,00 & 3,50 & 1,554 &, 50 & ,851 \\
\hline \multirow{5}{*}{$\begin{array}{l}\text { The teaching } \\
\text { criteria in } \\
\text { particular }\end{array}$} & $\begin{array}{l}\text { I think the criteria that are used to assess the teaching- } \\
\text { portfolio are comprehensive }\end{array}$ & 3 & 3 & 5 & 12 & 8 & 3,62 & 4,00 & 1,293 &, 50 & $0.015^{\star}$ \\
\hline & $\begin{array}{l}\text { The distinction between the teaching-portfolio ratings of } \\
\text { strength and excellence are apparent to me }\end{array}$ & 2 & 9 & 4 & 10 & 6 & 3,28 & 4,00 & 1,306 & ,50 & ,557 \\
\hline & $\begin{array}{l}\text { I think the teaching criteria used for promotion at UKZN } \\
\text { unfairly favours those who have an education-related } \\
\text { qualification }\end{array}$ & 5 & 8 & 5 & 7 & 6 & 3,03 & 3,00 & 1,451 &, 50 & 1,00 \\
\hline & $\begin{array}{l}\text { I think teaching should be a core criterion that is assessed } \\
\text { for promotion to full-professor at UKZN }\end{array}$ & 3 & 13 & 3 & 7 & 5 & 2,97 & 2,50 & 1,326 &, 50 & ,701 \\
\hline & $\begin{array}{l}\text { I think the teaching criteria are easier to meet than research } \\
\text { criteria at UKZN }\end{array}$ & 5 & 8 & 5 & 11 & 2 & 2,90 & 3,00 & 1,269 &, 50 & 1,00 \\
\hline
\end{tabular}

${ }^{\star} p<0.05$ 
Table 5: Group mean comparisons - Perspectives on promotions

\begin{tabular}{|c|c|c|c|c|c|c|c|c|c|c|c|c|c|c|c|c|}
\hline \multirow{2}{*}{$\begin{array}{l}\text { Perspectives } \\
\text { about: }\end{array}$} & \multirow{2}{*}{ Item } & \multirow{2}{*}{$\begin{array}{l}\text { Group } \\
\text { statistics }\end{array}$} & \multicolumn{2}{|c|}{ Gender } & \multicolumn{2}{|c|}{$\begin{array}{c}\text { Race } \\
\text { (excl Foreign } \\
\text { nationals) }\end{array}$} & \multicolumn{2}{|c|}{ Age } & \multicolumn{2}{|c|}{ Discipline } & \multicolumn{2}{|c|}{$\begin{array}{l}\text { Number of years in } \\
\text { rank }\end{array}$} & \multicolumn{2}{|c|}{$\begin{array}{l}\text { Intention to become } \\
\text { a full professor in } \\
\text { future }\end{array}$} & \multicolumn{2}{|c|}{$\begin{array}{c}\text { Intention to by } \\
\text { apply for } \\
\text { promotion } \\
\end{array}$} \\
\hline & & & $\begin{array}{l}\text { Female } \\
(n=12)\end{array}$ & $\begin{array}{c}\text { Male } \\
(\mathrm{n}=19)\end{array}$ & $\begin{array}{l}\text { Black } \\
(n=12)\end{array}$ & $\begin{array}{l}\text { White } \\
\text { (n=11) }\end{array}$ & $\begin{array}{c}<=50 \text { years } \\
(n=16)\end{array}$ & $\begin{array}{c}>50 \\
\text { years } \\
(n=15)\end{array}$ & $\begin{array}{c}\text { Sciences } \\
(n=20)\end{array}$ & $\begin{array}{c}\text { Social } \\
\text { Sciences } \\
(n=11)\end{array}$ & $\begin{array}{c}<5 y e a r s \\
(n=15)\end{array}$ & $\begin{array}{c}>=5 \text { years } \\
(n=16)\end{array}$ & $\begin{array}{c}\text { No } \\
(n=11)\end{array}$ & $\begin{array}{c}\text { Yes } \\
(n=20)\end{array}$ & $\begin{array}{c}\text { No } \\
(n=14)\end{array}$ & $\begin{array}{c}\text { Yes } \\
(n=17)\end{array}$ \\
\hline \multirow{8}{*}{$\begin{array}{l}\text { Expectations } \\
\text { regarding } \\
\text { promotion to } \\
\text { full professor }\end{array}$} & \multirow{4}{*}{$\begin{array}{l}\text { At UKZN I think once } \\
\text { you become an } \\
\text { associate professor, } \\
\text { your peers expect } \\
\text { you to become a full- } \\
\text { professor }\end{array}$} & Mean & 3,270 & 3,580 & 3,820 & 2,820 & 3,530 & 3,400 & 3,320 & 3,730 & 3,860 & 3,130 & 3,550 & 3,420 & 3,210 & 3,690 \\
\hline & & Std. Dev & 0,905 & 1,261 & 0,982 & 1,250 & 1,246 & 1,056 & 1,157 & 1,104 & 1,099 & 1,088 & 1,128 & 1,170 & 1,251 & 1,014 \\
\hline & & $\mathrm{t}$ & \multicolumn{2}{|c|}{$-0,770$} & \multicolumn{2}{|c|}{2,086} & \multicolumn{2}{|c|}{0,316} & \multicolumn{2}{|c|}{$-0,967$} & \multicolumn{2}{|c|}{1,83} & \multicolumn{2}{|c|}{0,29} & \multicolumn{2}{|c|}{$-1,13$} \\
\hline & & $\begin{array}{l}p \\
d\end{array}$ & \multicolumn{2}{|c|}{$\begin{array}{l}0,448 \\
0,282\end{array}$} & \multicolumn{2}{|c|}{$\begin{array}{l}0.050^{*} \\
0,890\end{array}$} & \multicolumn{2}{|c|}{$\begin{array}{l}0,754 \\
0,113\end{array}$} & \multicolumn{2}{|c|}{$\begin{array}{l}0,344 \\
0,363\end{array}$} & \multicolumn{2}{|c|}{$\begin{array}{l}0,08 \\
0,668\end{array}$} & \multicolumn{2}{|c|}{$\begin{array}{l}0,78 \\
0,113\end{array}$} & \multicolumn{2}{|c|}{$\begin{array}{l}0,27 \\
0,422\end{array}$} \\
\hline & \multirow{4}{*}{$\begin{array}{l}\text { I think there is little } \\
\text { difference between } \\
\text { the remuneration of } \\
\text { associate professors } \\
\text { and full-professors at } \\
\text { UKZN }\end{array}$} & Mean & 3,000 & 2,840 & 3,360 & 2,550 & 3,130 & 2,670 & 2,680 & 3,270 & 3,000 & 2,810 & 2,820 & 2,950 & 3,000 & 1,240 \\
\hline & & Std. Dev & 0,775 & 1,259 & 1,027 & 1,036 & 1,356 & 0,724 & 1,157 & 0,905 & 1,177 & 1,047 & 1,250 & 1,026 & 2,810 & 0,981 \\
\hline & & $\mathrm{t}$ & 0,4 & & & & 1,1 & & & & & 46 & & & & \\
\hline & & $\begin{array}{l}p \\
d\end{array}$ & $\begin{array}{l}0,6 \\
0\end{array}$ & & & & $\begin{array}{l}0,2 \\
0,4\end{array}$ & & & & & 65 & & & & \\
\hline & & Mean & 3,000 & 2,680 & 3,550 & 2,550 & 3,130 & 2,470 & 2,630 & 3,090 & 3,210 & 2,440 & 2,640 & 1,629 & 2,640 & 2,940 \\
\hline & I think the promotion & Std. Dev & 1,095 & 1,930 & 1,368 & 1,036 & 1,407 & 1,246 & 1,383 & 1,300 & 1,251 & 1,365 & 2,890 & 1,197 & 1,550 & 1,181 \\
\hline & procedures are & $\mathrm{t}$ & 0, & & & & 1,3 & & & & & 63 & & & & \\
\hline $\begin{array}{l}\text { The } \\
\text { promotions }\end{array}$ & transparent at UK $\angle \mathrm{N}$ & $\begin{array}{l}p \\
d\end{array}$ & $\begin{array}{l}0,5 \\
0,2\end{array}$ & & & & $\begin{array}{l}0,1 \\
0,4\end{array}$ & & & & & 12 & & & & \\
\hline process at & Ithink the time-lines & Mean & 3,730 & 2,890 & 3,450 & 2,820 & 3,470 & 2,930 & 3,000 & 3,550 & 3,710 & 2,750 & 2,910 & 3,370 & 2,790 & 3,560 \\
\hline & for the promotion- & Std. Dev & 1,009 & 1,197 & 1,128 & 1,250 & 1,246 & 1,100 & 1,291 & 0,934 & 1,139 & 1,065 & 1,136 & 1,212 & 1,188 & 1,094 \\
\hline & applications & $\mathrm{t}$ & 2, & & & & 1,2 & & & & & 39 & & & & \\
\hline & $\begin{array}{l}\text { procedure are } \\
\text { appropriate at UKZN }\end{array}$ & $\begin{array}{l}p \\
d\end{array}$ & $\begin{array}{l}0, \\
0,\end{array}$ & & & & $\begin{array}{l}0,2 \\
0,4\end{array}$ & & & & & $24^{*}$ & & & & \\
\hline & At UKZN, I think & Mean & 2,270 & 2,630 & 2,090 & 1,136 & 2,930 & 2,070 & 2,580 & 2,360 & 2,790 & 2,250 & 2,730 & 2,370 & 2,640 & 2,380 \\
\hline & support, from senior & Std. Dev & 0,786 & 1,257 & 2,730 & 1,009 & 1,223 & 0,799 & 1,170 & 1,027 & 1,051 & 1,125 & 1,421 & 0,895 & 1,336 & 0,885 \\
\hline & staff, for associate & $\mathrm{t}$ & -0 & & & & 2,2 & & & & & 35 & & & & \\
\hline Support for & $\begin{array}{l}\text { professors who want } \\
\text { to apply for }\end{array}$ & $\mathrm{p}$ & 0,3 & & & & 0.0 & & & & & 19 & & & & \\
\hline $\begin{array}{l}\text { promotions } \\
\text { applications }\end{array}$ & & Mean & 3,270 & 2,630 & 3,000 & 2,450 & 3,270 & 2,470 & 2,950 & 2,730 & 3,070 & 2,690 & 2,360 & 3,160 & 2,290 & 3,380 \\
\hline & for developing a & Std. Dev & 1,104 & 1,383 & 1,414 & 1,214 & 1,387 & 1,125 & 1,311 & 1,348 & 1,328 & 1,302 & 1,362 & 1,214 & 1,267 & 1,147 \\
\hline & $\begin{array}{l}\text { teaching-portfolio, } \\
\text { for promotion to full- }\end{array}$ & $\mathrm{t}$ & 1,3 & & & & 1,7 & & & & & 80 & & & & \\
\hline & professor is readily & $p$ & 0,1 & & & & 0,0 & & & & & 43 & & & & \\
\hline & available at UKZN & $d$ & 0,5 & & & & 0,6 & & & & & 89 & & & & \\
\hline
\end{tabular}




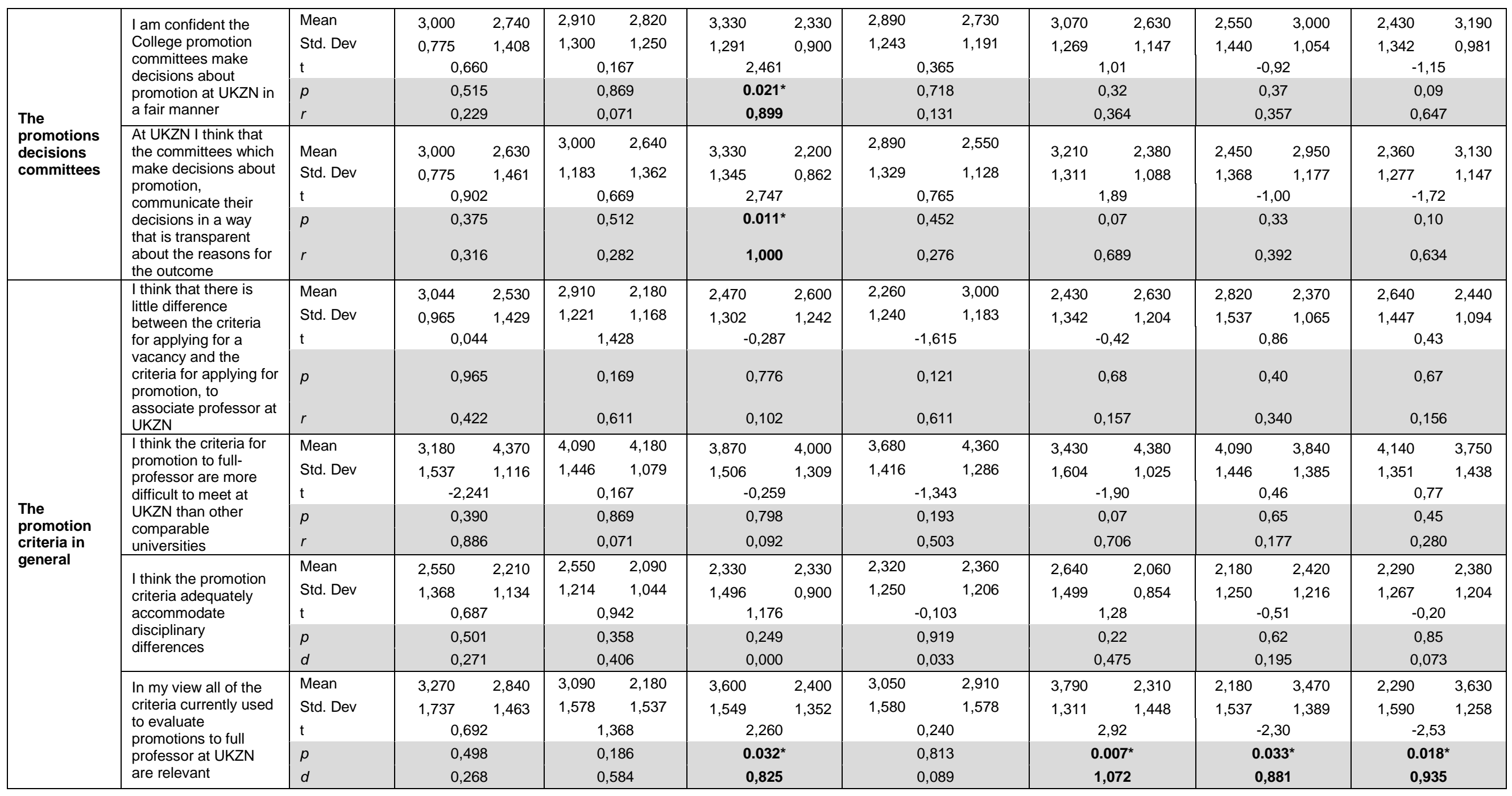




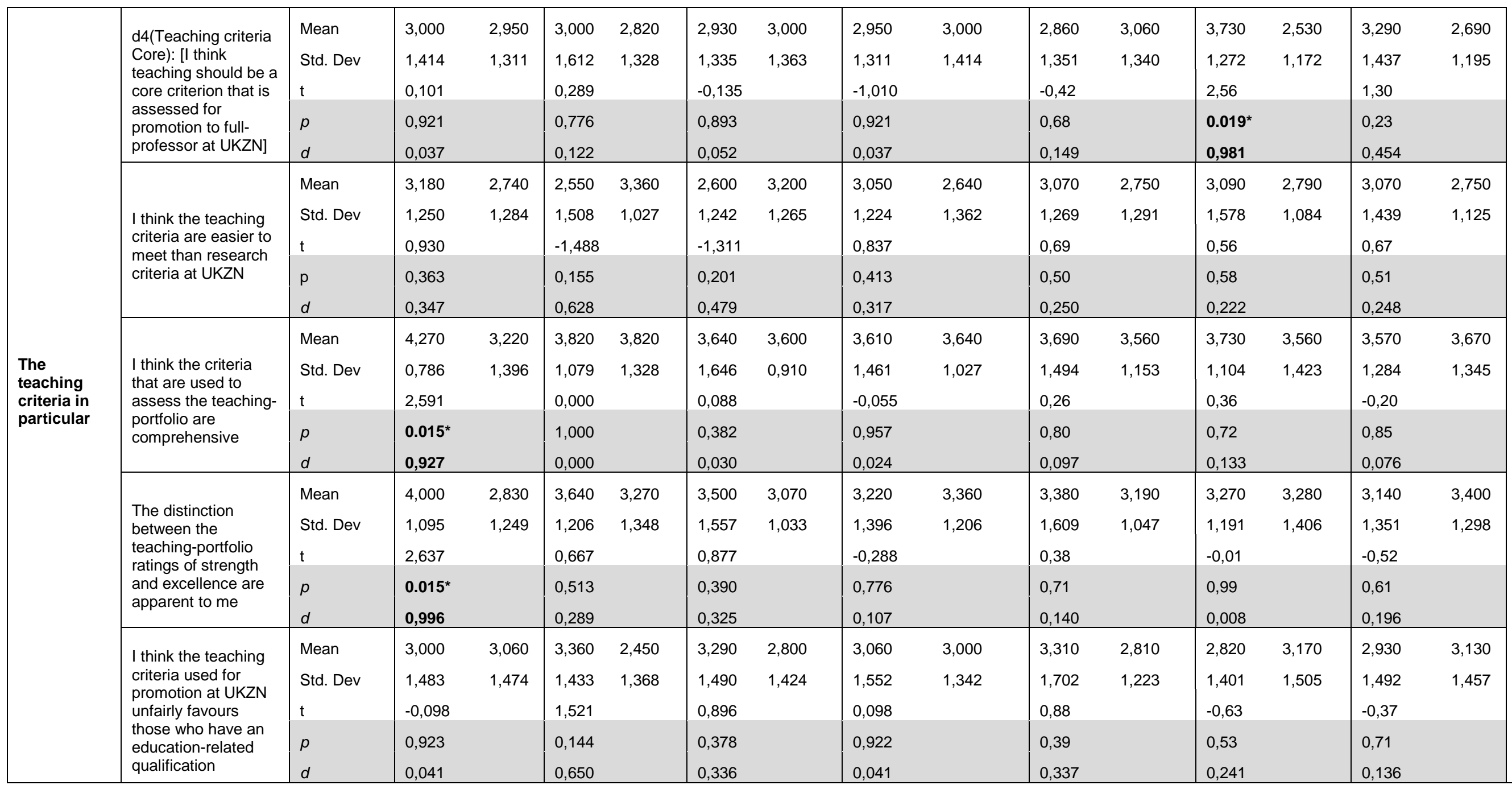

where ${ }^{*} p<0.05 ; d>.700$ 
However, irrespective of age or time in rank most associate professors were dissatisfied with the level of support for promotion applications available from senior staff. Given that the number of full professors is declining at the university (Figure 4) this result was not unexpected. However, it does point to a potential crisis in terms of staff development within the professoriate. Younger associate professors actively seeking support but not finding it may end up disillusioned and eventually become reluctant to apply for promotion. The risk here is that the longer they remain in the rank the more unlikely they are to become full professors and, the vicious cycle of the shrinking professoriate will continue. This problem is not unique to UKZN, Buch et al. (2011, 40) and Gardner and Blackstone (2013, 423) also showed that associate professors did not have mentors and were less likely to receive any support in terms of their career trajectory to full professor. Thus the university needs to consider creative alternatives to providing opportunities for support that are accessible to aspirant full professors.

Perspectives that the promotion criteria (both teaching and research) are difficult to meet were also expected because the criteria for the professoriate are generally more difficult to achieve than criteria for the junior ranks of lecturer and senior lecturer (Subbaye and Vithal 2015, 17). However, no national empirical data is currently available to confirm or refute that the UKZN criteria are more difficult to meet than at other comparable universities in South Africa. This is an area that requires further research. Yet another expected finding about the promotion criteria was that they did not adequately accommodate disciplinary differences. This finding is linked to a change in the research criterion in 2008 from faculty-specific to universitywide; and may be explained by how this criterion is applied by the College committees that make promotion decisions. The university-wide application of the teaching criterion and its evaluation (via the teaching portfolio) has remained relatively constant for more than a decade at UKZN (Vithal et al. 2013, 322). An interviewee's comment about the lack of recognition for community engagement criterion in the promotion highlights the point that for promotions awarded from 2009-2013, no academic, at any rank level, was promoted on this criterion (Subbaye and Vithal 2015, 17). Given that the scope of academic work, particularly in the rank of associate professor, has broadened (Toews and Yazedjian 2007, 121; Matthews 2014, 5) are the current promotion criteria too narrow or inflexible?

Notwithstanding the historical use of the teaching criterion, those who aspired to become full professors thought that teaching should not feature as a core criterion in the promotion decision. The literature offers a variety of explanations which could assist in explaining this finding. Firstly, these associate professors may perceive research as the key driver for promotion (Cretchley et al. 2014, 3). Secondly aspirant full professors may associate their 
professorial identities with research accomplishments (Rayner et al. 2010, 623). Thirdly, they may want to keep their options for inter-institutional mobility open by focusing their efforts on the more widely -used research criterion (Altbach 2015, 6). Fourthly, it is conceivable that those who intend to become full professors perceive that being assessed on teaching will lower the status of being a full professor especially if they want to be recognised as leading scholars, which they associate with research productivity (Bitzer 2008, 277).

Ironically, those who did not want to become full professors thought that teaching should be a criterion for promotion. These divergent perspectives about the (non) inclusion of teaching as a criterion for promotion, need not be irreconcilable and may reflect the respondents' commitment to teaching within the framework of their current work and its relationship to their future plans about the professoriate (Wattiaux, Moore, Rastani and Crump 2010, 3372).

The literature shows that the toll of teaching obligations is heavier on women (Zulu 2013, 753; Dlamini and Adams 2014, 127) and that women have a tendency to 'gravitate towards teaching' (Obers 2014, 116). Hence it came as no surprise that more female respondents in this study had positive perspectives on teaching as a criterion for promotion than men. Johnston (1998, 68) found that Australian women academics participated more in professional development activities related to teaching than male academics which may account for why, in this study, women were more knowledgeable about the criteria used to assess teaching, better able to make a firm judgment on the comprehensiveness of the criteria and were more clear about the different teaching portfolio ratings than men. These perspectives on teaching offers some insight as to why those women who applied for promotion to associate professor in the period 2009-2013 had better teaching evaluations than men (Subbaye and Vithal 2016, 11). Women may have a better understanding of the teaching requirements which may have contributed to their success rates. A counterpoint could be that the women who participated in this study may have applied for promotion to associate professor and were evaluated with excellence in teaching in the past, which in turn may contribute to their positive predispositions towards teaching that were revealed in this survey.

The dominant forces (described in the literature review) explaining Blacks underpresentation in the professoriate were attributed to the unsupportive, chilly climate in the academy; market-forces luring candidates to better paying jobs resulting in high staff turnover, the pipeline issue of not having sufficient numbers of suitably qualified Blacks' and, resource constraints to support and grow the Black professoriate. These external forces may be compounding the pressure to become a full professor was which strongly felt by Black academics in this study. This finding is especially relevant in the current South African context 
of transformation of the professoriate and the drive for employment equity. One implication, in post-apartheid South Africa, is that Black associate professors who perceiving greater pressure than their White counterparts to perform and excel, are consequently experiencing a greater need to prioritise key activities in a context that expects them to attain the rank of full professor (Mkhwanzi and Baijnath 2003, 110; Wattiaux et al. 2010, 3373). But as cautioned by Potgieter (2002, 27) since Black academics are faced with having to live up to often unrealistic goals and performance expectations, not supporting or mentoring and providing constructive feedback about career their development can have serious consequences for the number of Blacks in the academy (Potgieter 2002, 33).

\section{CONCLUSION}

South African universities are experiencing a shrinking professoriate which is not being replenished at the rates required to sustain the growth of the higher education sector. Therefore, it was encouraging that the majority of the participants in this study wanted to become full professors - but this aspiration was dependent on their age and how long they remained in the rank of associate professor. This study is useful in reviving discussion and debate on how academic promotion processes and criteria could serve as enablers or barriers to the rank of full professor and contribute to addressing equity in South African universities. While there is some support, it is limited to developing teaching portfolios for promotions. Universities could also consider advocating for peer-mentoring support or guiding self-help groups, by creating spaces to allow associate professors to come together to discuss their careers more broadly and promotions opportunities in particular. (Wilson 2012, 1). Discussions between academic staff and university leadership about the promotion criteria seem overdue. This study raises two important questions about promotion criteria. Does the historical emphasis on research and teaching criteria in academic promotions adequately reward and recognise the current nature of academic work? Should the criteria be broadened or differentiated? These questions (and others) need to be addressed so that there is a shared understanding about what is required to become a full professor in South Africa

South African Whites are disproportionately over-represented in the professoriate (Figure 2) and more males occupy the highest ranks of university leadership as vice-chancellors and deputy vice-chancellors (see: Subbaye and Vithal 2016, 4). Therefore, Blacks and women's continued under-representation in the professoriate implies that university leadership positions are likely to remain White and male dominated in the foreseeable future. In-depth qualitative studies are required to understand; Blacks' experiences as associate professors and specifically, the perspectives of black senior lecturers and their rank progression plans, given their under- 
representation at the rank of associate professor (Figure 2) and, why women's academic careers seem to stall at the rank of associate professor (Figure 3). Finally, it can be argued that the cumulative effect of supporting Blacks and women, to be promoted into the professoriate has the potential to create a critical mass of academics who could eventually transform knowledge production, leadership and decision making in South African higher education institutions.

\section{NOTES}

1. The act stipulates that employers should implement affirmative action for designated groups (Blacks, women and people with disabilities); and put in place measures that 'ensure the equitable representation of suitable qualified people from designated groups in all occupational categories and levels in the workforce' (section 15.1d, 18).

2. According to the Employment Equity Act (1998), Blacks 'is a generic term which means Africans, Coloured and Indians' (Chapter 1, 6).

\section{REFERENCES}

Altbach, P. G. 2015. What counts for academic productivity in research universities? International Higher Education Winter 79: 6-7.

Baldwin, R. G. and R. T. Blackburn. 1981. Academic career as a developmental process. Journal of Higher Education 52(6): 598-614.

Bitzer, E. M. 2008. The professoriate in South Africa: Potentially risking status inflation. South African Journal of Higher Education 22(2): 265-281.

Boshoff, N. 2005. The representation of women academics in higher education in South Africa: Progress in the pipeline? South African Journal of Higher Education 19(2): 359-377.

Bunting, I. and N. Cloete. 2010. Institutional types in higher education in South Africa. Centre for Higher Education and Transformation (CHET). South Africa. http://www.chet.org.za/files/ uploads/events/dialogues_he/Session\%202a\%20Institutional\%20Types\%20in\%20SA\%20HE\% 20-\%20Ian\%20Bunting.pdf

Buch, K. Y., A. Rorrer Huet and L. Roberson. 2011. Removing the barriers to full Professor: A mentoring program for Associate Professors. Change: The Magazine of Higher Learning 43(6): 38-45.

CHE see Council on Higher Education.

Council on Higher Education. 2015. Content analysis of the baseline institutional submissions for Phase 1 of the quality enhancement project. CHE: Institutional audit directorate. Pretoria, South Africa.

Council on Higher Education. 2016. South African Higher Education Reviewed: Two decades of democracy. CHE. Pretoria, South Africa.

Crawford, C., R. Burns and R. H. McNamara. 2012. Promotion to Full Professor: Moving beyond tenure and Associate Professorship. Journal of Criminal Justice Education 23(1): 41-64. DOI: 10.1080/10511253.2011.645491

Cretchley, P. C., S. L. Edwards, P. O'Shea, J. Sheard, J. Hurst and W. Brookes. 2014. Research and/or learning and teaching: A study of Australian professors' priorities, beliefs and behaviours. Higher Education Research \& Development 33(4): 649-669. DOI: 10.1080/07294360.2013.863836

Department of Higher Education and Training. 2016a. Higher Education Management Information System: HEMIS Database - Dataset of university staff from 2009-2014 extracted February 2016. Department of Higher Education and Training. Pretoria. South Africa.

Department of Higher Education and Training. 2016b. Report on the evaluation of the 2014 
Universities' research outputs. Pretoria. South Africa. http://www.dhet.gov.za/Policy\%20and \%20Development\%20Support/Report\%20on\%20the\%20outcomes\%20of\%20the\%202014\%20 universities\%20research\%20outputs.pdf

De Winter, J. C. F. 2013. Using the student's t-test with extremely small sample sizes. Practical Assessment Research \& Evaluation 18(10): 1-12.

DHET see Department of Higher Education and Training.

Dlamini, E. T. and J. D. Adams. 2014. Patriarchy: A case of women in institutions of higher education. Perspectives in Education 32(4): 121-133.

Enders, J. 2001. A chair system in transition: Appointments, promotions and gate-keeping in German Higher education. Higher Education 41(1/2): 3-25.

Finnegan, D. E. and A. E. 2009. Assistant to 'Full': Rank and the development of expertise. Teachers College Record 111(2): 443-479.

Field, A. 2009. Discovering statistics using SPSS. London: Sage Publications Ltd.

Gardner, S. K. and A. Blackstone. 2013. 'Putting in your time': Faculty experiences in the process of promotion to Professor. Innovative Higher Education 38(5): 411-425.

Green, R. G. 2008. Tenure and promotion decisions: The relative importance of teaching, scholarship, and service. Journal of Social Work Education 44(2): 117-127.

Habib, A. 2014. Underfunding to blame for our paucity of PhDs. http://blogs.wits.ac.za/vc/wp-content/ uploads/sites/3/2014/09/28645918-4674938.pdf (accessed 21 March 2016).

HESA see Higher Education South Africa.

Higher Education South Africa. 2011. Proposal for a National Programme to develop the next generation of academics for South African higher education: A generation of growth, ed. S. Badat. Grahamstown, South Africa.

Jansen J. 2015. Shortage of senior black academics. http://www.dispatchlive.co.za/news/shortage-ofsenior-black-academics/ (accessed 21 March 2016).

Johnston, S. 1998. Women and professional development in higher education: A search for understanding. International Journal for Academic Development 3(1): 64-71.

LimeSurvey. 2015. An Open Source survey tool. Project Team/Carsten Schmitz. Project Hamburg, Germany. http://www.limesurvey.org

Lindholm, J. A. 2004. Pathways to the Professoriate: The role of self, others, and environment in shaping academic career aspirations. The Journal of Higher Education 75(6): 603-635.

Macfarlane, B. 2011. Professors as intellectual leaders: Formation, identity and role. Studies in Higher Education 36(1): 57-73.

Matthews, K. R. 2014. Perspectives on midcareer faculty and advice for supporting them. Collaborative on Academic Careers in Higher Education (COACHE). Harvard Graduate School of Education. USA.

McAlpine, L. 2014. Over time, how do post-Ph.D. scientists locate teaching and supervision within their academic practice? Teaching in Higher Education 19(8): 835-846. DOI:10.1080/13562517.2014.934356

Mkhwanazi, V. and N. Baijnath. 2003. Equity development programmes for academic staff at South African higher education institutions: Progress and promise. South African Journal of Higher Education 17(3): 106-113.

Obers, N. 2014. Career success for women academics in higher education: Choices and challenges. South African Journal of Higher Education 28(3):1107-1122.

Ornstein, M., P. Stewart and J. Drakich. 2007. Promotion at Canadian universities: The intersection of gender, discipline, and institution. Canadian Journal of Higher Education 37(3): 1-25.

Pedro, F. 2009. Continuity and change in the academic profession in European countries. Higher Education in Europe 34(3): 412-429. 
Potgieter, C. 2002. Black academics on the move. Centre for Higher Education Transformation. Sunnyside, South Africa: 1-43

Price, M. 2014. Staff transformation at UCT. http://www.uct.ac.za/dailynews/archives/?id=8752 (accessed 21 March 2016).

Probert, B. 2013. Teaching focused academic appointments in Australian universities: Recognition, specialisation or stratification? Discussion Paper 1. Office for Learning and Teaching. http://www.olt.gov.au/resource-teaching-focused-academic-appointments (accessed 3 January 2015).

Rayner, S., M. Fuller, L. McEwen and H. Roberts. 2010. Managing leadership in the UK university: A case for researching the missing professoriate? Studies in Higher Education 35(6): 617-631.

Reybold, L. E. 2003. Pathways to the professoriate: The development of faculty identity in education. Innovative Higher Education 27(4): 235-252.

Sanfey, H. 2010. Promotion to professor: A career development resource. The American Journal of Surgery 200(4): 554-557.

Sehoole, C. and E. O. Ojo. 2015. Challenges and opportunities for new faculty in South African higher education. In Young faculty in the twenty-first century: International perspectives, 253-283.

South African Government. 1998. Employment Equity Act. Act No. 55 of 1998. Government Gazette No. 19370. Office of the President. Cape Town: South Africa

SPSS (IBM SPSS Statistics v23). 2015. Statistical Package for Social Sciences. Release v.23. Chicago: International Business Machines.

Subbaye, R. 2014. Teaching in academic promotions at research universities. Ph.D. in progress, School of Education (Discipline of Higher Education), University of KwaZulu-Natal, Durban.

Subbaye, R. and R. Vithal. 2015. Teaching criteria that matter in university academic promotions. Assessment and Evaluation in Higher Education. DOI:10.1080/02602938.2015.1082533

Subbaye, R. and R. Vithal. 2016. Gender, teaching and academic promotions in higher education. Gender and Education. DOI: 10.1080/09540253.2016.1184237

Teferra, D. 2014. Charting African higher education - Perspectives at a glance. International Journal of African Higher education 1(1): 9-21

Toews, M. L. and A. Yazedjian. 2007. The three-ring circus of academia: How to become the ringmaster. Innovative Higher Education 32(2):113-122.

UKZN (University of KwaZulu-Natal). 2011. UKZN Academic Promotion Policy (HRE/08/08CO); UKZN Academic Staff Promotion Procedures and Guidelines (HRE/06/08/SC). Durban: Division of Human Resources.

Vithal, R., R. Subbaye and D. North. 2013. Valuing teaching in university academic promotions. Alternation 9: 318-342.

Waaijer, C. F. 2015. The coming of age of the academic career: Differentiation and professionalization of German academic positions from the 19th Century to the Present. Minerva 53(1): 43-67. DOI: 10.1007/s11024-014-9264-z

Wattiaux, M. A., J. A. Moore, R. R. Rastani and P. M. Crump. 2010. Excellence in teaching for promotion and tenure in animal and dairy sciences at doctoral/research universities: A faculty perspective. Journal of Dairy Science 93(7): 3365-3376. DOI:10.3168/jds.2010-3070

Wilson, R. 2012. Why are Associate Professors so unhappy? Chronicle of Higher Education. http://chronicle.com/article/Why-Are-Associate-Professors/132071/

Young, P. 2006. Out of balance: Lecturer's perceptions of differential status and rewards in relation to teaching and research. Teaching in Higher Education 11(2): 191-202.

Zulu, C. 2013. Women academics' research productivity at one university campus: An analysis of dominant discourses. South African Journal of Higher Education 27(3): 750-767. 